UDC 331.14:159.9

JEL Classification: D74, J52, D21

http://doi.org/10.21272/mmi.2019.1-22

Adeyinka Joseph Adewole,

Adekunle Ajasin University, Nigeria

Kayode Joseph Ogunyemi,

Adekunle Ajasin University, Nigeria

Toyin W. Otapo,

Ph.D., Adekunle Ajasin University, Nigeria

\title{
IMPLICATIONS OF EFFECTIVE CONFLICT MANAGEMENT ON ORGANIZATIONAL PERFORMANCE: CASE STUDY OF NIGERIAN BOTTLING COMPANY PLC
}

Abstract. This paper summarizes the arguments and counterarguments within the scientific discussion on the implications of effective conflict management on organizational performance. The main purpose of the research is to examine the relationship between effective conflict management and organisational performance in Nigeria. The study covers matters such as causes of conflict, types of conflict, conflict development and strategies for managing conflicts as well as means of managing conflict in an attempt to enhance organizational productivity. Systematization literary approach for solving the problem is Simple Regression Analysis. The major instrument used for the collection of data for this study was a questionnaire. This was done in order to give an equal chance to each respondent to be heard, in order for an objective outcome to be achieved. One hundred (100) set of the questionnaire were distributed, out of which ninety-eight of them were properly filled and returned. The restatement of the hypothesis revealed that conflict management leads to improve organizational performance. The result also revealed that there is a positive relationship between conflict management (independent variable) and improved organizational performance (dependent variable). This study also shows that conflict management contributes to improved organizational productivity. The result also revealed that there is a positive relationship between conflict management (independent variable) and improved organizational performance (dependent variable). This study also shows that conflict management contributes to improved organizational productivity. The study, therefore, recommends that Organizations should manage identified conflicts effectively to improve organizational performance; there should be a clearly defined task allocation, which could lead to job satisfaction and enrichment driven, in order to reduce the rate of conflict; the dispute settlement procedure should be well circulated and implemented among the warring parties without fear or favour; the emergence of conflict does arise as a result of overlapping of responsibilities, however an attempt should be made to design duties among workers, in such a way that will enhance efficiency; Managers should imbibe the culture of good remuneration package through motivation, since motivation will go a long way in improving productivity and reduce conflict; Management should maintain and create a conducive environment to strengthen the cordiality between the top-level managers and subordinates because autocratic leadership style can easily result in inefficiency and crisis; Communication and effective flow of information should be encouraged so as to discourage any form of communication breakdown; Customers' satisfaction should be given adequate priority so that the employees will not suffer undue punishment by the management.

Keywords: conflict, management, organizational performance, efficiency.

Introduction. Organization is an identifiable social entity whose members pursue multiple goals collectively. The pursuance of these goals is done side by side with their personal goals and aspirations through their coordinated activities and relationships. Hence, organisation has people, materials and goals that are achieved through coordination.

Cite as: Adewole, A. J., Ogunyemi, K. J., \& Otapo, T. W. (2019) Implications of Effective Conflict Management on Organizational Performance: Case Study of Nigerian Bottling Company PLC. Marketing and Management of Innovations, 1, 257-280. http://doi.org/10.21272/mmi.2019.1-22 
An organization exists to provide goods and services that people desire. These goods and services are the products of the behaviours of workers who occupy different levels of the organizational structure. These people have different cultures, skills and educational background as well as different perceptions, roles, expectations and values.

Schramm-Nielsen (2002) defines a conflict as a state of serious disagreement and argument about something perceived to be important by at least one of the parties involved. Conflict is inevitable in human societies and runs through all organizations; both profit and non - profit making organizations. Conflict is one of the most difficult challenges a manager faces. Hence, management are duty bound to resolve conflicts properly for the sake of increasing organisational performance because the result of such action will result to good communication, time management, good cooperation and increase organisational performance.

Fadipe (2000), sees conflict as a form of disagreement in an establishment between two individuals or groups who have cause to interact formally or informally. Similarly, Miller and King (2005), see it as basically a disagreement between two or more individuals or groups over compatible goals. Conflict, therefore, is a process of incompatible behaviours. It may involve the interference or disruption by one person or group of persons, or in some way or ways which make another action less likely to be effective.

According to Akaniij (2005), conflict inevitably means that people are working against each other, in such a manner that what one wants is incompatible with that which another wants. It could bring about competition in the pursuit of goals. What the competitor gets comes at the expense of others or the job. It is therefore counter-productive, disruptive, unnatural, and produces a deviation from the free flow of events. A major factor that can throw parties into a state of incompatibility is their perception of the issue at hand or issue of interest. There are other factors that can contribute to the creation of conflict in organizations like task interdependence, scarce resources, goal incompatibility, communication failures, individual differences and poorly designed reward system Mgbekem (2004).

Conflict is an unpleasant fact in any organization as long as people compete for jobs, resources, power, recognition and security. Organizational conflict can be regarded as a dispute that occurs when interests, goals or values of different individuals or groups are incompatible with each other Henry (2009). This results in a situation whereby they frustrate each other in an attempt to achieve their objectives. Conflict arises in groups because of the scarcity of freedom, position, and resources. People who value independence tend to resist the need for interdependence and, to some extent, conformity within a group. People who seek power, therefore, struggle with others for position or status within the group.

Conflict is a part of organizational life and may occur between individuals, between the individual and the group, and between groups. While conflict is generally perceived as dysfunctional, it can also be beneficial because it may cause an issue to be presented in different perspectives. The conflict has both positive and negative effects. It can be positive when it encourages creativity, new looks at old conditions, the clarification of points of view, and the development of human capabilities to handle interpersonal differences. Conflict can be negative when it creates resistance to change, establishes turmoil in the organization or interpersonal relations fosters distrust, builds a feeling of defeat, or widens the chasm of misunderstanding.

Unfortunately, the term «conflict» has only the connotation of «bad» for many people; so much so that they think principally in terms of suppression, giving little or no attention to its more positive side. Imazai et al., 2002, emphasizes this by stating that it seems entirely likely that many, if not most, organizations need more conflict, not less. Jung (2003), also stated that the absence of conflict may indicate autocracy, uniformity, stagnation, and mental fixity; the presence of conflict may be indicative of democracy, diversity, growth, and self-actualization.

Henry (2009), complements this statement arguing that conflict is not the opposite of cooperation but a mechanism that allows perceiving benefits of cooperative work. Furthermore, conflict is considered 
psychologically and socially healthy. It is psychologically healthy because it provides a breather for frustrations and enables a feeling of participation and even of joy. And it is sociable healthy because it encourages opposition to the status quo and provides conditions for social changes and democracy stemming from pluralism and respect to diversity. Therefore, according to lkeda et al., (2005), conflict is ubiquitous, not necessarily dysfunctional and can be required to defy people to perform and stimulate progress.

However, the establishment and continued existence of the organization through the realization of set goals and objectives require the continuous and effective functioning of its material input with the human element being indispensable. The human elements required to facilitate goals attainment often engage in disagreement and variance over factors such as; interest, views, style of management, among others. The reactionary effect due to the perceived incompatibilities resulting typically from some form of interference or opposition is known as conflict. Azamoza (2004), observed that conflict involves the total range of behaviours and attitudes that are in the opposition between owners/managers on one hand and working people on the other. It is a state of disagreement over issues of substance or emotional antagonism and may arise due to anger, mistrust or personality clashes.

Conflict arises as a result of divergent interests. The interest of the employer is to get the best out of his workers, also the interest of workers in terms of wages and salaries and condition of employment, therefore, there is no way that conflict would not emerge in an organization, though, it might not be exposed quickly until the whole organization is affected, particularly the aspect of management and productivity.

Although conflict is not always bad, unnecessary conflict creates problems for both the organization and the organization's members.

It has been argued that conflict often consumes the large and solid amount of time and energy which otherwise could be directed towards the accomplishment of organization and individual goals.

As conflict increases, satisfaction, innovation, involvement, redistribution and performance may decrease, while tiredness and absenteeism may increase.

Furthermore, Thompson Strickland (2002) support the view that if workers in an organization are motivated towards the targeted result, through incentives and the rewarding of good performance in form of salaries, stock options, fringe benefits and so on, the conflict would not likely affect the level of productivity. This study is designed to examine the impact of effective conflict management on organization performance, many organizations nowadays collapsed due to one factor or other; the most common of such factor is conflict.

Conflict in any organization may not allow the organization to achieve its set objectives if not properly managed. Hart (2000) asserted that successful organizations in the future must create the capability to absorb conflict during the organization's life cycle. The capability here refers to a conflict management mechanism in order to minimize the rate of conflict and improve performance. The Centre for Effective Dispute Resolution (2005), supports the perception of an increase in organizational conflicts with some hard facts. Their research efforts reported a $17 \%$ increase in organizational conflict, measured by the more than 115,000 employment tribunal applications in 2004 in the United Kingdom. The serious problem of resolving what will be the level of conflict management attainment that will create an enabling environment for their organization, because without peace and co-operation in an organization's daily activities no organization will be able to sustain and stay ongoing concern.

The study aimed at establishing the relationship between effective conflict management and organisational performance. Specifically, the study is with a view to identify and examine the various type of conflict, identify and discuss various sources of conflict, examine the influence of conflict on organizational performance, identify and discuss the effectiveness of various types of conflict management strategies, identify and discuss various strategies for management of conflict, emphasize the relationship between conflict and organisation. 
The hypotheses to be tested in this study are presented in a null form which states that effective conflict management does not lead to improving organizational performance. Secondly, effective conflict management does lead to improving organizational performance

This research is mainly on effective conflict management and organizational performance in Nigerian Bottling Company PIc. The findings and recommendation would be useful to both public and private organization and it is subjected to certain limitations since it is very cumbersome to go through the whole population, the project focused on Nigerian Bottling Company PLC.

This organization is chosen because of ease in accessibility and also being an organization with diverse goals, conflicts situation will always be manifesting in the life of the organization. The limitation of the study is insufficient financial resources, time and materials.

This study will be of value to organizations both public and private in order for them to identify some silent causes of conflicts and to be able to manage the situation judiciously using some of the conflict management strategies. The study will also arouse government interest to see the need for providing adequate resources to public organizations in order to minimize the rate of conflict in these organizations. The study will also provide a platform for the management of organizations to direct resources appropriately in order to minimize conflicts situations in the workplace. The study is also expected to be of great value to scholar and practitioners in the field of conflict management, public relations and public administration.

The Nigerian Bottling Company PLC (NBC) was incorporated in November 1951, as a subsidiary of the A.G. Leventis Group with the franchise to bottle and sell Coca-Cola products in Nigeria.

From a humble beginning as a family business, the company has grown to become a predominant bottler of non-alcoholic beverages in Nigeria, responsible for the manufacture and sale of over 33 different Coca-Cola brands. Other popular brands of beverage produced by the company are Eva Water, Five Alive fruit juice and the newly introduced Burn energy drink.

The company presently has 13 bottling facilities and over 80 distribution warehouses located across the country. Since production started, NBC PLC has remained the largest bottler of non-alcoholic beverages in the country in terms of sales volume, with about 1.8 billion bottles sold per year, making it the second largest market in Africa.

Today, the company is part of the Coca-Cola Hellenic Bottling Company (CCHBC), one of Coca-Cola Company's largest anchor bottlers worldwide. CCHBC operates in 28 countries, serving 540 million consumers and selling over 1.3 billion-unit cases of beverage annually.

The company recently embarked on a restructuring exercise to expand further its market share and growth profit. It invested in a new state of the art can filling and packing line at the Apapa plant. The plant has since begun to produce the first soft drink can that is wholly packaged in Nigeria. This is in addition to a new bottling plant in Abuja, investment in the upgrade of other manufacturing infrastructure, distribution and delivery facilities.

Literature Review. Robbins and Judge (2009) define conflict as a process that begins where one party perceives that another party has negatively affected or is about to negatively affects something that the first party cares about. This is a very apt definition because it emphasizes that conflict is about perceptions, not necessarily real-hard facts. It points to the emotional nature of the conflict, by referring to a word like "care», it states that more than one party is involved and that there may be a future component attached to it.

According to Shapiro (2006), conflict is a process of social interaction. It involves a struggle over claims to resources, power, status, beliefs, preferences and desires. Darling and Walker (2007) linked this idea to the organization by stating that, even when conflict is a natural phenomenon in social relations (as natural as harmony), it can nevertheless be managed within organizations. They add that conflict may have both positive as well as negative consequences within the organization, the submission +above 

Case Study of Nigerian Bottling Company PLC

blend with the fact that conflict can never be totally eliminated within organizations but can be efficiently managed in order to move organizations to greater height and performance level.

The conflict that supports the goals for the group and improves the group's performance can be classified as functional conflict (Darling and Walker, 2007). This type of conflict is constructive in nature and the base assumption is that it will have a positive effect on the organisation's performance. For example, this type of conflict can cause ideas, beliefs and assumptions to be challenged (Bagshaw, 1998). This, in turn, can lead to innovation and the willingness to consider fresh tactics. There can also be information exchange, honest and free expression of opinions (Rivers, 2005). Constructive conflict can also be a catalyst for action for the mere anticipation of future conflict can instigate action (Darling and Walker, 2007). Conflict is a key ingredient to organisational change - functional conflict can therefore not only be responsible for the organisational improvement, but also for organisational change (Olakunle, 2008).

On the other hand, according to Olakunle (2008), conflict is dysfunctional when it absorbs organisational efforts and resources without producing anything when it deflects attention from basic purposes, and perhaps, when it leads to actions which consciously or unconsciously sabotage and subvert primary organisational goals. Dysfunctional or destructive conflict breaks an organisation down. Interdepartmental conflicts can, for instance, disturb resourcefulness in another department (Maltz and Kohli, 2000). Other instances of dysfunctional conflict regularly found in the organisation include interference with another function's work by withholding information and the forming of coalitions to block certain proposals (Barclay, 1991). There are also passive ways to use conflict to be destructive. This might include a lack of responsiveness to requests, a deliberate rigid adherence to organisation procedures to stop or delay progress (Hart, 2000).

Organisations that promote more of functional conflict will perform better which is preferred than dysfunctional conflict because it supports group goals and improves organisational performance.

Conflict can arise in different situations. Deutch and Coleman (2006) identified some of the causes of conflict to include the following; differences in knowledge, beliefs and basic values; competition for position, power and recognition; a need for tension release; a drive for autonomy; personal dislike; and differing perception or attributes brought about by the organisational structure, different role structure, heterogeneity of the workforce, environmental changes, differences in goals, diverse economic interest, loyalties of groups, and value discrepancies, which were all considered at various stages as major causes of conflict in organisations.

According to Havenga (2004), indicated that causes of conflict at the level of organisation could also include resource availability; affirmative action programmes, the scope and content of workload, the introduction of new management techniques; and differences of a cultural and racial nature. A typology that further categorises sources of conflict is offered by Kreitner and Kinicki (2001), who differentiate between structural factors (causes) that is, those that develop from within the organisation and originate from the manner in which work is organised, and secondly personal factors, which emerge as a result of individual differences among employees.

Robbins and Judge (2009) identified some sources and causes of conflict in the organisation to include: scarce resources, task dependency, communication breakdown, personality clashes and role ambiguities.

According to Oyedipo, Lawal and others the following types of conflict that can arise in an organization.

1. Inter-organizational conflict: - This kind of conflict usually emerge in organizations. It is caused by economic factors, such as inflations, salary etc.

2. Intergroup conflict: - This may arise between two trade unions, between two departments or between management and workers while attempting to implement the policies and programmes of their organization. 
3. Interpersonal conflict: This is a conflict between two or more individual. It is usually caused by personality differences for instance conflict between management subordinates managers and his comanager.

4. Intrapersonal conflict: This takes place within an individual in an organization. It could result from incongruence both personal and organization goals

One of the important questions in business has been why some organisations succeeded while others failed. Organisation performance has been the most important issues for every organisation be it profit or non-profit one. It has been very important for managers to know which factors influence an organisation's performance in order for them to take appropriate steps to initiate them. However, defining, conceptualising and measuring performance has not been an easy task. Researchers among themselves have different opinions and definitions of performance, which remains to be a contentious issue among organisational researchers (Barney, 2008). For example, according to Javier (2007), as cited in Nikbin et al (2010), performance is equivalent to the famous 3 Es (i.e. economy, efficiency and effectiveness) of a certain programme or activity. However, according to Daft (2009), organisational performance is the organisation's ability to attain its goals by using resources in an efficient and effective manner. Quite similar to Daft (2009) Richardo and Wade (2010) defined organisational performance is the ability of the organisation to achieve its goals and objectives. Organisational performance has suffered from not only a definition problem but also from a conceptual problem. This is what Hefferman and Flood (2006) stated: «That as a concept in modern management, organisational performance suffered from problems of conceptual clarity in a number of areas. The first was the area of definition while the second was that of measurement. The term performance was sometimes confused with productivity. Productivity was a ratio depicting the volume of work completed in a given amount of time. The performance was a broader indicator that could include productivity as well as quality, consistency and other factors».

In result-oriented evaluation, productivity measures were typically considered. Richardo and Wade (2010) argued that performance measures could include result-oriented behaviour (criterion-based) and relative (normative) measures, education and training, concepts and instruments, including management development and leadership training which were the necessary building skills and attitudes of performance management. Hence, from the above, the term 'performance' should be broader based on which include effectiveness, efficiency, economy, consistency behaviour and normative measures (Richardo and Wade, 2010).

To be able to understand conflict well, it must be viewed as a process, it can be understood if considered as a dynamic having five task stages.

1. Latent Conflict (Conditions): Creating conflict which may be competition for scarce resource drive for autonomy roles clashes.

2. Perceived Conflict: The basic condition by one or all the parties, the parties recognize, difference of opinion, incompatible goals or values effort to deem the other party or the implementation of opposing actions.

3. Felt Conflicts: The perception of the conflict by one or both parties now leads to a change in behaviour, internal tension now starts to build up in one or both parties.

4. Manifest Conflict: The building of conflict occasioned by a change in behaviour, now intensifies and the intensification is high so much that the change in behaviour is now noticed by all the parties involved, this stage is usually marked by such common negative behavioural change as stealing, strike sabotage and so on.

5. Conflict Aftermath: When the conflict is obvious to everybody, there's usually an action to take a resolve the conflict, the way the conflict is resolved usually fells whether there still be further conflict or there will be desirable change such as effective co-operation or the attainment of one goal or the other. 
The effects of conflict in any organization can be viewed from two perspectives that are functional and dysfunctional. The functional outcomes of conflict include:

- it initiates a search for ways to eliminate and resolve problems;

- conflict may serve as an indication for increasing organization resources;

- conflict produces competition among various groups;

- potential problems may surface for the solution to be derived;

- conflict can stimulate creativity;

- the conflict also has a strategic implementation for bosses and their subordinate.

The dysfunctional aspects of conflict include:

- communication breakdown both horizontally, vertically;

- intergroup and interpersonal rivalries and jealousy;

- widespread arbitration and appeals to higher authority;

- inflexible and unaccommodating attitudes;

- conflict can lead to feeling to anxiety, guilt frustration and hostility among organizational participants.

In summary, the functional aspects support the goals of the organization and improve productivities, these are constructive forms of conflict while the dysfunctional aspect grinders organizational productivity.

However, it is worthy to note that conflict effects on the individual and the organization are of course not mutually exclusive, the ways in which individuals perceive a conflict may have an important effect on the organization. This position depended on the belief that organizations exist primarily to achieve goals not to palate individual members. As a result, in a definitional form functional or dysfunctional is determined by the conflict effects on the organization.

A successful approach to conflict management seeks not to eliminate conflict or to avoid it but to learn how to manage it creatively and constructively.

The approach to conflict management is varied as the causes sources and context since conflict is inevitable but it could be minimized to reduce its negative effort on the welfare of the organization.

The method of managing conflict can be grouped into structural and interpersonal approaches.

1. Structural approach: This approach is aimed at altering and structures that have a considerable effect on the behaviour of individuals, such methods include:

- change procedure of work to reduce interaction between conflicting parties;

- change the organization of work e.g transfer personnel;

- change the physical layout e.g democrat of office to create structural barriers and to reduce the numbers of interaction;

- add more resource to solve the problem of scarce resource.

2. Interpersonal approach: attempt to effect changes in the behaviour of the individual by means of:

- Withdrawal: a kind of strategic retreat which can be either real or stimulated in some conflict particularly labour management, conflict withdrawal may not be a satisfactory alternative but maybe last result manoeuvre to drive the conflict under group.

- Conflict may also be solved by third party intervention: - It entails the intervention of an outside neutral party such as arbitrator or consultant who collect facts and provides a solution.

- Win-Lose approach: overpowering conflict and suppressing one's adversary, extracting compliance by authority, it is possible in organizations that have high concern for work and low concern for employees.

- Smoothing: this requires letting the conflicting parties recognize that with a little patience they will find that all is right, the approach is used by the organization that has high concern for employees and low concern for production. 
- Neutrality: avoidance of conflict by being neutral. This receives the necessity of dealing with a situation that would arise conflict e.g withdrawal from social responsibility. It is ultimate and alienation, this approach may be geared towards encouraging parties to confront each other, identifying their differences and work them out.

- Bargaining: this is the middle of the road management by means of compromise, it is always called win-lose approach because neither party win nor lose entirely disagreement is resolved through accommodation and adjustment, it required agreeable even to sacrificing indication and arbitration.

- The last approach is problem-solving: this solution is time-consuming in the short run, but time conserving the long - run, it appears to be useful in conflict particularly in labour management.

Here, disagreement is viewed as an inevitable result of the fact that strong-minded people have convictions about what is right and therefore, disagreement must be worked out mutually and identified alternatives must be sought, in this way, conflicting parties jointly identify goal priorities as areas of common interest and subsequently position to determine intergroup course of action. In this way, the problem-solving approach has been viewed to be effective because of its advantages of being preventive, effective and communication and avoiding resentments and resistance to change.

In organizations, meeting, seminars, committees, task force and sensitivity training groups are also useful methods in problem-solving approach. Managing conflict in an organization involves the following five-stage:

1. Analyse the conflict: What is involved here is to understand and analyse the nature scope dimension and types of conflict. To do this require asking the question and interview the parties in conflict.

2. Determination of conflict management strategies: Once the general understanding has been established and the parties involved in the conflict has been questioned and interviewed the next is to select and analyse the most appropriate strategy, the following are the main strategies and tools of conflict management, they are mechanism for resolving all types of conflict in an organization.

Open encounter and negotiation strategy: This is a strategy of constructive engagement in which the parties in conflict engage one another in issues and attempt to arrive at a mutually desirable action or outcome by modifying their points of views or negotiation their differences, the aim is to restore effective working relationship or achieve a workable solution.

Arbitration by the third party: This is used when the division between the warring factions is so intense that open confirmation cannot be used because of the faction have taken definite position and their division are very fundamental, the arbitration who act at the request of and his chosen by both parties in conflict, examine the facts and make the decision to settle the conflict.

Meditation by a third party: Here, the third party comes into the act as peacemaker between opposing sides in order to bring about peace and agreement. Unlike the arbitration, the mediator does not act as a judge, all he does is to find common ground and bring the warring parties together.

Separation of the parties: This is a very drastic strategy involving redeployment of warring parties to separate departments or branches. The separation may be permanent or for a temporary period, to cool of tension and nerves. Difficult and sensitive interpersonal conflict can be resolved in this way especially where the basis of the conflict is emotional.

3. Change in role expectations: this can be done by bringing about changes in the structure conflicting role by sympathetic discussion, clear job description and democratic of duties.

4. Carry out pre-negotiation with parties involved in the conflict: this stage involved the discussion with the parties involved, the impacts of negotiation towards the realization of organizational goals or conflict resolution in the organization.

5. Negotiation Stages: this stage is the one in which the conflict between the parties is negotiated out by making use of any appropriate strategy. 

Case Study of Nigerian Bottling Company PLC

6. Establish post-negotiation activities: this stage involved the implementation of the outcome of decision or judgment of the negotiation stage towards conflict resolution.

According to Barker et al (1987), conflicts have a negative and positive effect on the individual employees and organization at large. When conflict arises in an organization, it needs to be managed for the sale of organization growth, survival and enhance productivity (Ford, 2007).

Not all conflict is bad and not all are good, according to Hocker and Wilmot (1995). Conflict can create a negative impact on the group but may also lead to positive effects depending on the nature of the conflict. The positive effects of conflict are:

Improving the quality and decisions, stimulating involvement in discussion and building group cohesion, in addition, conflict also will be potentially destructive in groups especially when it consumes individual members energies of the organization.

However, conflict can interfere with group process and create so much interpersonal hostility that group members may become unwilling or unable to work with others in achieving the organization objectives, thus rendering them unproductive. Unsolved conflict tends to grow into a bigger conflict, the more it grows the greater the chance of collecting more problems (Knippen and Green 1999). Similarly, some of these problems, which might arise due to conflict, are lack of cooperation, poor communication, wasted time and contagious conflict shown in Figure 1.

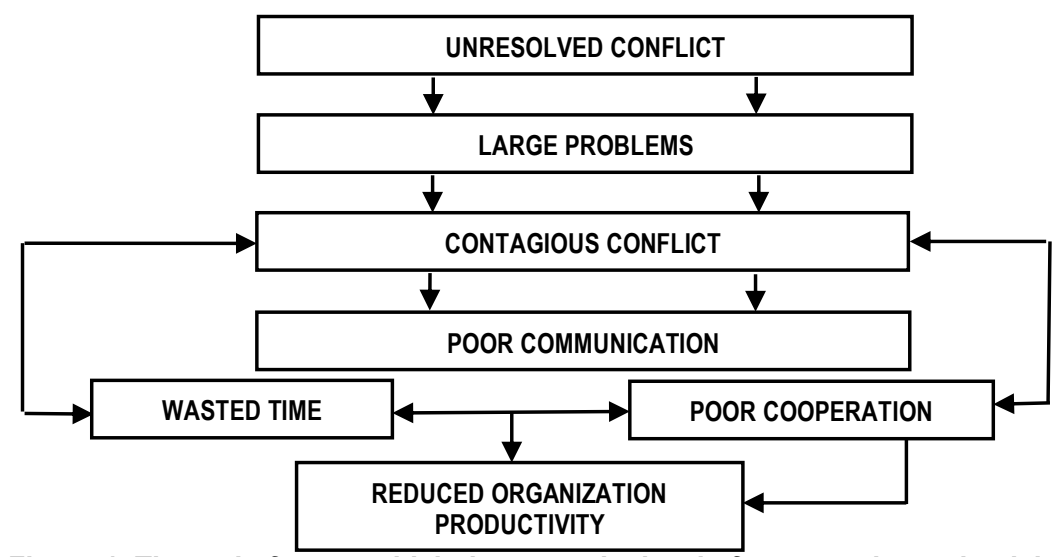

Figure 1. The main factors which decrease the level of company's productivity Source: Knippen and Green (1999)

Management should manage conflicts properly in their organization for the sake of increasing organizational productivity. The outcome of managing conflict in the organization shown in Figure 2.

If the conflict is managed properly by applying the best courses of action, the organization would increase its productivity in terms of utilizing scarce resources and achieving the organizational objectives. Conflict improves decision-making outcomes especially on task-related conflict and group productivity by increasing the quality constructive criticism and individual adopting a devil's advocate role (Amason, 1996; Schewnk and Cosier 1980). Research has also found that task-related conflict is beneficial to the organization since it allows the exchange of ideas and assists better performance among the group members, (John 1995). Another benefit including improved group learning and accuracy in situation assessment (Flol 1994), promoted the development of new ideas and approaches (Baron, 1991) and achieve high-quality decisions since individual confront problems (Schwenk and Valacich 1994). Conflict is seen as a productive force that can stimulate members of the organization to increase their knowledge and skills and contribute to organizational innovation and productivity. Robinson et al (1994) advocate that 

Case Study of Nigerian Bottling Company PLC

managing conflict towards constructive action is the best approach in resolving conflict in the organization. When conflict arises, we need to ability to manage them properly, so that it becomes positive forces, rather than a negative force, which would threaten the individual or group. Parker (1974) argued that if the conflict arises and they are not managed properly will lead to the delay of work, disinterest and lack of action and in extreme cases, it might lead to the complete breakthrough in the group. Finally, unmanaged conflict may result in withdrawal of individual and unwillingness on their part to participate in other groups or assist with various group action programmes in the organization.

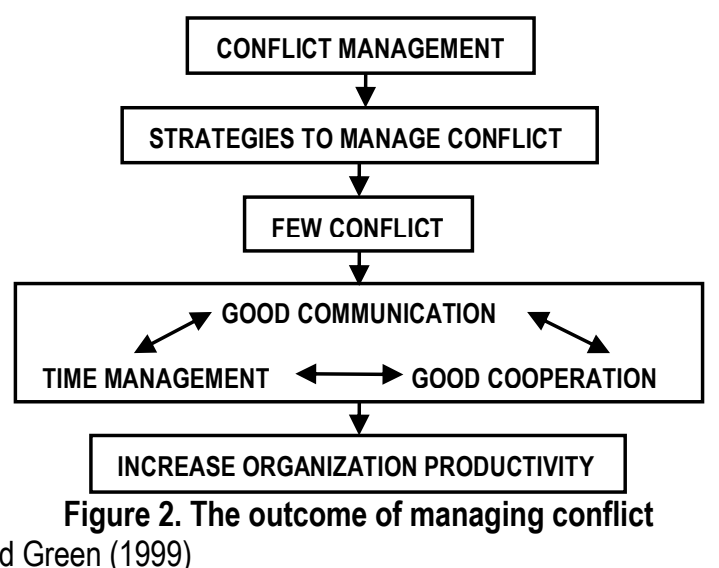

Source: Knippen and Green (1999)

Methodology. Methods are the specification of procedures for collecting and analysing data and necessary to define and solve problems at hand. This section discusses the relevant methods, techniques and statistics employed in the collection of data and information required in the course of assessing the impact of effective conflict management on organization performance. The population of the study comprises of all staff working under the Nigerian Bottling Company PLC. This population extends beyond the shores of southwestern Nigeria. As such, all staff of the Nigerian Bottling Company PLC in the six geopolitical zones of the country made up the population. The sample size was drawn from the population of staff of the Nigerian Bottling Company PLC in which, all the staff in the South-western part of Nigeria was selected and purposive sampling technique was adopted in selecting samples from the population for the purpose of the study. This sampling technique was adopted so as to ensure that only respondents that are of equal significance to the study were selected. Thus, their responses are bound to be reliable and may be used for generalization.

The data for the study will be obtained from two sources, which are primary and secondary sources. Both sources were explored in order to get comprehensive and adequate information needed for the research work, which eventually assisted in providing platforms for the accurate recommendation for the study. The primary data is the one which raw information is collected by the user from a specific place, which in the case of Nigerian Bottling Company PLC. This source is usually explored at the actual time in which required information is needed. It enables the researcher to have direct contact with the object, with the view to gather correct information. The primary data for this study was collected through the administration of the questionnaire. This is the kind of information gathered by someone else for some purposes, which another person can use during the cause of carrying out research work. This method is always used to compliment the primary data. The secondary data for this study were obtained from textbooks, newspapers, journals websites etc. A questionnaire is a designed form which consists of a set questions sent to people (respondents) for completion, to gather information for analysis and to confirm 
A. J. Adewole, K. J. Ogunyemi, T. W. Otapo. Implications of Effective Conflict Management on Organizational Performance: Case Study of Nigerian Bottling Company PLC

relevant research questions which are later returned for analysis. The questionnaire employed for this study consists of two (2) section «A» (table 1) and «B». Section «A» has to do with the socio-economic characteristics of the workers of Nigerian Bottling Company PLC and it contains six (6) questions while section «B» contains twenty (20) major questions. Each question has options from which respondents were to make choices. The options available for the respondents include; Strongly Agreed (SA), Agreed (A), Undecided (U), Disagreed (D), and Strongly Disagreed (SD). This is expected to help the researcher to understand the level of maturity of the respondents which goes a long way in affecting their responses that will be gathered through a questionnaire.

Table 1. Sets of questionnaire: Section A

\begin{tabular}{|c|}
\hline \multicolumn{2}{|c|}{ SECTION A Section A: (Bio-Data) } \\
\hline Sex: $\quad$ (a) Male, (b) Female. \\
\hline Marital Status: (a) Single, (b)Married, (c) Divorced, (d) Widowed, (e) Separated. \\
\hline Age: (a) 21-30years, (b) 31-40 Years,(c) 41-50years, (d) 51-60 Years, (e) 60years and Above. \\
\hline Position/Status: (a) Top Level Management, (b) Middle Level Management, (c) Lower Level Management. \\
\hline Educational Qualification: (a) SSCE/O'Level, (b) ND/NCE, (c) HND /B.Sc., (d) MBA/ M.Sc/ICAN/CIBN and Other. \\
\hline Years in Service: (a)1-5years, (b) 6-10years, (c)11-20 years, (d) 21-30 years, (e) 31 and above. \\
\hline
\end{tabular}

Sources: developed by the authors.

Table 2. Sets of questionnaire: Section B

\begin{tabular}{|c|c|c|c|c|c|}
\hline STATEMENT & SA & A & $\mathrm{U}$ & D & $\mathrm{SD}$ \\
\hline 1 & 2 & 3 & 4 & 5 & 6 \\
\hline Non-consolidation of employees before taking key decisions may lead to conflict. & & & & & \\
\hline $\begin{array}{l}\text { It is argued that conflict arises as a result of the overlapping roles of some members of the } \\
\text { organization }\end{array}$ & & & & & \\
\hline $\begin{array}{l}\text { Differences in value and perception among members of a group within an organization may } \\
\text { result in group conflict }\end{array}$ & & & & & \\
\hline $\begin{array}{l}\text { It is argued that conflict occurs as a result of the difference in values among organizational } \\
\text { members }\end{array}$ & & & & & \\
\hline $\begin{array}{l}\text { It is argued that conflict arises when individual workers 'fight' for personal goals, ignoring } \\
\text { organizational goals and organizational wellbeing }\end{array}$ & & & & & \\
\hline It is believed that when company scarce resources often lead to conflict in an organization & & & & & \\
\hline $\begin{array}{l}\text { It is assumed that conflict brings about personality clashes among employees in an } \\
\text { organization }\end{array}$ & & & & & \\
\hline $\begin{array}{l}\text { It is assumed that the introduction of new technology to workers that do not adapt to new } \\
\text { changes can lead to conflict in an organization }\end{array}$ & & & & & \\
\hline $\begin{array}{l}\text { It is assumed that the introduction of new technology to workers that do not adapt to new } \\
\text { changes can lead to conflict in an organization }\end{array}$ & & & & & \\
\hline $\begin{array}{l}\text { It is believed that harassment in the workplace such as sexual or racial/harassment also } \\
\text { results in conflict }\end{array}$ & & & & & \\
\hline The inter-group conflict has a positive effect on the organization's performance & & & & & \\
\hline Conflict leads to low-level of employees' performance & & & & & \\
\hline Conflict leads to high - resistance to change & & & & & \\
\hline $\begin{array}{l}\text { Conflicts interfere with group cohesiveness and create interpersonal hostility in such a way } \\
\text { that members may become unwilling to work with each other in achieving the organizational } \\
\text { objectives }\end{array}$ & & & & & \\
\hline $\begin{array}{l}\text { Unresolved conflict brings poor communication within the organization and by extension } \\
\text { improved organizational performance }\end{array}$ & & & & & \\
\hline It has been contended that avoidance $s$ & & & & & \\
\hline
\end{tabular}


A. J. Adewole, K. J. Ogunyemi, T. W. Otapo. Implications of Effective Conflict Management on Organizational Performance: Case Study of Nigerian Bottling Company PLC

Continue Table 2

\begin{tabular}{|c|c|c|c|c|c|}
\hline 1 & 2 & 3 & 4 & 5 & \\
\hline $\begin{array}{l}\text { It is believed that there is a positive relationship between conflict and avoidance and improved } \\
\text { organizational performance }\end{array}$ & & & & & \\
\hline $\begin{array}{l}\text { It is obvious that the use of a well-structured schedule of duty in an organization reduces } \\
\text { indecent of conflict }\end{array}$ & & & & & \\
\hline $\begin{array}{l}\text { It is attested that putting in place a formal procedure for conflict resolution can prevent future } \\
\text { conflict }\end{array}$ & & & & & \\
\hline Effective conflict management leads to improve organization performance & & & & & \\
\hline $\begin{array}{l}\text { Do you agree that the use of a well-structured schedule of duty in an organization will reduce } \\
\text { the incident of conflicts }\end{array}$ & & & & & \\
\hline
\end{tabular}

Note: Please indicate by marking $(\sqrt{ })$ as to the extent in which you Strongly Agreed (SA), Agreed (A) Undecided

$(U)$, Disagreed (D) or Strongly Disagreed (SD), in the following statements.

Sources: developed by the authors.

In this paper, simple regression analysis methods were used with the aid of the Statistical Package for Social Science (SPSS) from the primary data collected in the field. This was done to drawn inferences thereby, giving a clue whether to accept or reject the null hypothesis. Hence, the formula for calculating regression analysis adopted for this research work is given below:

$$
Y=a+b x
$$

where:

$$
\begin{aligned}
& a=y-b x \\
& \mathrm{~b}=\frac{\mathrm{n} \sum \mathrm{xy}-\left(\sum \mathrm{x}\right)\left(\sum \mathrm{y}\right)}{\mathrm{n}\left(\sum \mathrm{x}^{2}\right)-\left(\sum x\right)^{2}}
\end{aligned}
$$

$y=$ simple arithmetic mean $y ; x=$ simple arithmetic mean of $x ; y=$ dependent variable; $x=$ independent variable; $a=$ intercept of the line; $b=$ slope of the line; $n=$ number of population.

Results. This section aimed at analysing and discussing data collected from the respondents. The data collected at this stage were analysed and interpreted for drawing inferences that formed the basis for conclusion and recommendations. The objective here is determined from the various responses of respondents whether there is an impact of effective conflict management on organizational performance. In this study, one hundred sets of questionnaires were administered out of which 98 were properly filled and returned. Thus, the ninety-eight (98) sets of questionnaire formed the basis for this study.

Table 3. Respondents' Sex Distribution

\begin{tabular}{|c|c|c|c|c|c|}
\hline \multicolumn{2}{|c|}{} & Frequency & Percent & Valid Percent & Cumulative Percent \\
\hline \multirow{3}{*}{ Valid } & male & 57 & 58.2 & 58.2 & 58.2 \\
\cline { 2 - 6 } & female & 41 & 41.8 & 41.8 & 100.0 \\
\cline { 2 - 6 } & Total & 98 & 100.0 & 100.0 & \\
\hline
\end{tabular}

Sources: Researcher's Field Survey, 2015

Data analysis in the above table shows that $57(58.2 \%)$ were male, while $41(41.8 \%)$ were female. This shows that majority of the respondents were male. 
A. J. Adewole, K. J. Ogunyemi, T. W. Otapo. Implications of Effective Conflict Management on Organizational Performance: Case Study of Nigerian Bottling Company PLC

Table 4. Respondents' Sex Distribution

\begin{tabular}{|c|c|c|c|c|c|}
\hline \multicolumn{2}{|c|}{} & Frequency & Percent & Valid Percent & $\begin{array}{c}\text { Cumulative } \\
\text { Percent }\end{array}$ \\
\hline \multirow{3}{*}{ Valid } & Single & 58 & 59.2 & 59.2 & 59.2 \\
\cline { 2 - 6 } & Married & 36 & 36.7 & 36.7 & 95.9 \\
\cline { 2 - 6 } & Widowed & 4 & 4.1 & 4.1 & 100.0 \\
\cline { 2 - 6 } & Total & 98 & 100.0 & 100.0 & \\
\hline
\end{tabular}

Sources: Researcher's Field Survey, 2015

The above table 4 shows that $58(59.2 \%)$ of the respondents were single, 36 (36.7) of them were married, $4(4.1 \%)$ were widowed. This shows that those greater portions of the respondent were either single or married.

Table 5. Respondents' Age

\begin{tabular}{|c|c|c|c|c|c|}
\hline \multicolumn{2}{|c|}{} & Frequency & Percent & Valid Percent & Cumulative Percent \\
\hline \multirow{4}{*}{ Valid } & $21-30$ years & 52 & 53.1 & 53.1 & 53.1 \\
\cline { 2 - 6 } & $31-40$ years & 29 & 29.6 & 29.6 & 82.7 \\
\cline { 2 - 6 } & $41-50$ years & 15 & 15.3 & 15.3 & 98.0 \\
\cline { 2 - 6 } & $51-60$ years & 2 & 2.0 & 2.0 & 100.0 \\
\cline { 2 - 6 } & Total & 98 & 100.0 & 100.0 & \\
\hline
\end{tabular}

Sources: Researcher's Field Survey, 2015

In table 5 above, $52(53.1 \%)$ respondents were between $21-30$ years of age, $29(29.6 \%)$ respondents were within the age bracket of 31-40 years, $15(15.3 \%)$ respondents were also between the age bracket of 41-50 years and $2(2.0 \%)$ respondents were also between the age bracket of 51-60.

From Table 6 below, 22(22.4\%) respondents were top management staffs, 48(48.0\%) respondents were middle management staffs and $29(29.6 \%)$ respondents were lower level management staffs.

Table 6. Respondents' Employment Status

\begin{tabular}{|c|c|c|c|c|c|}
\hline \multicolumn{2}{|c|}{} & Frequency & Percent & Valid Percent & Cumulative Percent \\
\hline \multirow{4}{*}{ Valid } & top level management & 22 & 22.4 & 22.4 & 22.4 \\
\cline { 2 - 6 } & middle level management & 47 & 48.0 & 48.0 & 70.4 \\
\cline { 2 - 6 } & low-level management & 29 & 29.6 & 29.6 & 100.0 \\
\cline { 2 - 6 } & Total & 98 & 100.0 & 100.0 & \\
\hline
\end{tabular}

Sources: Researcher's Field Survey, 2015

From table 7, $23(23.5 \%)$ respondents were holders of Secondary leaving certificates, $4(4.1 \%)$ respondents were holders of ND/NCE certificates, 67 (68.4\%) respondents were holders of HND/B.Sc certificates, 4 (4.1\%) respondents were either MBA/M.Sc/ICAN?CIBN honour degree.

Table 7. Respondents' Educational Qualification

\begin{tabular}{|c|c|c|c|c|c|}
\hline \multicolumn{2}{|c|}{} & Frequency & Percent & Valid Percent & Cumulative Percent \\
\hline \multirow{4}{*}{ Valid } & SSCE/O'level & 23 & 23.5 & 23.5 & 23.5 \\
\cline { 2 - 6 } & ND/NCE & 4 & 4.1 & 4.1 & 27.6 \\
\cline { 2 - 6 } & HND/B.Sc & 67 & 68.4 & 68.4 & 95.9 \\
\cline { 2 - 6 } & $\begin{array}{c}\text { MBA/M.Sc/ICAN/CIBN and } \\
\text { other }\end{array}$ & 4 & 4.1 & 4.1 & 100.0 \\
\cline { 2 - 6 } & Total & 98 & 100.0 & 100.0 & \\
\hline
\end{tabular}

Sources: Researcher's Field Survey, 2015 
A. J. Adewole, K. J. Ogunyemi, T. W. Otapo. Implications of Effective Conflict Management on Organizational Performance: Case Study of Nigerian Bottling Company PLC

From table 8 below $51(52 \%)$ respondents had working experience of $1-5$ years, $35(35.7 \%)$ respondents have been working between $6-10$ years, $8(8.2 \%)$ of respondents have also been working $11-20$ years, $4(4.1 \%)$ have been working between $21-30$ years.

Table 8. Respondents' Years of Working Experience

\begin{tabular}{|c|c|c|c|c|c|}
\hline \multicolumn{2}{|c|}{} & Frequency & Percent & Valid Percent & Cumulative Percent \\
\hline \multirow{4}{*}{ Valid } & 1-5years & 51 & 52.0 & 52.0 & 52.0 \\
\cline { 2 - 6 } & 6-10years & 35 & 35.7 & 35.7 & 87.8 \\
\cline { 2 - 6 } & $11-20$ years & 8 & 8.2 & 8.2 & 95.9 \\
\cline { 2 - 6 } & 21-30years & 4 & 4.1 & 4.1 & 100.0 \\
\cline { 2 - 6 } & Total & 98 & 100.0 & 100.0 & \\
\hline
\end{tabular}

Sources: Researcher's Field Survey, 2015

From table 9, $68(69.4 \%)$ of the respondents agreed to strongly agree that non-consolidation of employees before taking key decisions may lead to conflict, 30 (30.6\%) respondents agreed with the statement. None of the respondents choose undecided, disagreed and strongly agreed.

Table 9. Non-consolidation of employees before taking key decisions may lead to conflict.

\begin{tabular}{|c|c|c|}
\hline Responses & Frequency & Percentage \\
\hline Strongly Agreed & 68 & 69.4 \\
\hline Agreed & 30 & 30.6 \\
\hline Undecided & - & - \\
\hline Disagreed & - & - \\
\hline Strongly Disagreed & - & - \\
\hline Total & 98 & 100 \\
\hline
\end{tabular}

Sources: Researcher's Field Survey, 2015

From Table 10, it is revealed that 47 (48\%) of the respondents strongly agreed that conflict arises as a result of overlapping roles of some members of the organization, $49(50 \%)$ respondents agreed and 2 $(2 \%)$ were undecided with the statement.

Table 10. It is argued that conflict arises as a result of the overlapping roles of some members of the organization

\begin{tabular}{|c|c|c|}
\hline Responses & Frequency & Percentage \\
\hline Strongly Agreed & 47 & 48 \\
\hline Agreed & 49 & 50 \\
\hline Undecided & 2 & 2 \\
\hline Disagreed & - & - \\
\hline Strongly Disagreed & - & - \\
\hline Total & 98 & 100 \\
\hline
\end{tabular}

Sources: Researcher's Field Survey, 2015

From the table 11, $94(96 \%)$ respondents agreed (strongly agreed and agreed) differences in value and perception among members of a group within an organization may result in group conflict, while $2(2 \%)$ respondents are undecided and $2(2 \%)$ respondents disagreed to the assertion. 
A. J. Adewole, K. J. Ogunyemi, T. W. Otapo. Implications of Effective Conflict Management on Organizational Performance: Case Study of Nigerian Bottling Company PLC

Table 11. Differences in value and perception among members of a group within an organization may result in group conflict

\begin{tabular}{|c|c|c|}
\hline Responses & Frequency & Percentage \\
\hline Strongly Agreed & 18 & 18.4 \\
\hline Agreed & 76 & 77.6 \\
\hline Undecided & 2 & 2 \\
\hline Disagreed & 2 & 2 \\
\hline Strongly Disagreed & - & - \\
\hline Total & 98 & 100 \\
\hline
\end{tabular}

Sources: Researcher's Field Survey, 2015

From the table 12, $94(95.9 \%)$ respondents agreed (strongly agreed and agreed) that conflict occurs as a result of the difference in values among organizational members, while $2(2 \%)$ respondents are undecided and $2(2 \%)$ respondents disagreed to the assertion.

Table 12. It is argued that conflict occurs as a result of the difference in values among organizational members

\begin{tabular}{|c|c|c|}
\hline Responses & Frequency & Percentage \\
\hline Strongly Agreed & 21 & 21.4 \\
\hline Agreed & 73 & 74.5 \\
\hline Undecided & 2 & 2 \\
\hline Disagreed & 2 & 2 \\
\hline Strongly Disagreed & - & - \\
\hline Total & 98 & 100 \\
\hline
\end{tabular}

Sources: Researcher's Field Survey, 2015

From table 13 revealed that $84(85.7 \%)$ respondents agreed (strongly agreed and agreed) that conflict arises when individual workers 'fight' for personal goals, ignoring organizational goals and organizational wellbeing, while $4(4.1 \%)$ respondents are undecided and $10(10.2 \%)$ respondents disagreed to the assertion.

Table 13. It is argued that conflict arises when individual workers 'fight' for personal goals, ignoring organizational goals and organizational wellbeing

\begin{tabular}{|c|c|c|}
\hline Responses & Frequency & Percentage \\
\hline Strongly Agreed & 39 & 39.8 \\
\hline Agreed & 45 & 45.9 \\
\hline Undecided & 4 & 4.1 \\
\hline Disagreed & 10 & 10.2 \\
\hline Strongly Disagreed & - & - \\
\hline Total & 98 & 100 \\
\hline
\end{tabular}

Sources: Researcher's Field Survey, 2015

From the table 14 revealed that $64(65.3 \%)$ respondents agreed (strongly agreed and agreed) that when company scarce resources often lead to conflict in an organization, while $22(22.4 \%)$ respondents are undecided and $12(12.2 \%)$ respondents disagreed to the statement. 
A. J. Adewole, K. J. Ogunyemi, T. W. Otapo. Implications of Effective Conflict Management on Organizational Performance: Case Study of Nigerian Bottling Company PLC

Table 14. It is believed that when company scarce resources often lead to conflict in an

\begin{tabular}{|c|c|c|}
\hline \multicolumn{3}{|c|}{ organization } \\
\hline Responses & Frequency & Percentage \\
\hline Strongly Agreed & 4 & 4.1 \\
\hline Agreed & 60 & 61.2 \\
\hline Undecided & 22 & 22.4 \\
\hline Disagreed & 12 & 12.2 \\
\hline Strongly Disagreed & - & - \\
\hline Total & 98 & 100 \\
\hline
\end{tabular}

Sources: Researcher's Field Survey, 2015

From table 15 revealed that $28(28.6 \%)$ of the respondents agreed to strongly agree that conflict brings about personality clashes among employees in an organization, $64(65.3 \%)$ respondents agreed and 6 (6.1\%) choose undecided with the statement.

Table 15. It is assumed that conflict brings about personality clashes among employees in an organization

\begin{tabular}{|c|c|c|}
\hline Responses & Frequency & Percentage \\
\hline Strongly Agreed & 28 & 28.6 \\
\hline Agreed & 64 & 65.3 \\
\hline Undecided & 6 & 6.1 \\
\hline Disagreed & - & - \\
\hline Strongly Disagreed & - & - \\
\hline Total & 98 & 100 \\
\hline
\end{tabular}

Sources: Researcher's Field Survey, 2015

From the table 16 revealed that $78(79.6 \%)$ respondents agreed (strongly agreed and agreed) that introduction of new technology to workers that do not adapt to new changes can lead to conflict in an organization, while $8(8.2 \%)$ respondents are undecided and $12(12.2 \%)$ respondents disagreed to the statement.

Table 16. It is assumed that the introduction of new technology to workers that do not adapt to new changes can lead to conflict in an organization

\begin{tabular}{|c|c|c|}
\hline Responses & Frequency & Percentage \\
\hline Strongly Agreed & 14 & 14.3 \\
\hline Agreed & 64 & 65.3 \\
\hline Undecided & 8 & 8.2 \\
\hline Disagreed & 12 & 12.2 \\
\hline Strongly Disagreed & - & - \\
\hline Total & 98 & 100 \\
\hline
\end{tabular}

Sources: Researcher's Field Survey, 2015

From table 17 revealed that $54(55.1 \%)$ of the respondents agreed to strongly agree that that harassment in the workplace such as sexual or racial/harassment also results in conflict, $40(40.8 \%)$ respondents agreed and $4(4.1 \%)$ choose undecided with the statement. 
A. J. Adewole, K. J. Ogunyemi, T. W. Otapo. Implications of Effective Conflict Management on Organizational Performance: Case Study of Nigerian Bottling Company PLC

Table 17. It is believed that harassment in the workplace such as sexual or racial/harassment also results in conflict

\begin{tabular}{|c|c|c|}
\hline Responses & Frequency & Percentage \\
\hline Strongly Agreed & 54 & 55.1 \\
\hline Agreed & 40 & 40.8 \\
\hline Undecided & 4 & 4.1 \\
\hline Disagreed & - & - \\
\hline Strongly Disagreed & - & - \\
\hline Total & 98 & 100 \\
\hline
\end{tabular}

Sources: Researcher's Field Survey, 2015

It can be inferred from table 18 above revealed that $62(63.3 \%)$ of the respondents agreed (strongly agreed and agreed) to the assertion inter-group conflict has a positive effect on the organization's performance, $22(22.4 \%)$ respondents were undecided, while14 (14.2\%) respondents disagreed (disagreed and strongly disagreed) with the statement.

Table 18. The inter-group conflict has a positive effect on the organization's performance

\begin{tabular}{|c|c|c|}
\hline Responses & Frequency & Percentage \\
\hline Strongly Agreed & 32 & 32.7 \\
\hline Agreed & 30 & 30.6 \\
\hline Undecided & 22 & 22.4 \\
\hline Disagreed & 12 & 12.2 \\
\hline Strongly Disagreed & 2 & 2 \\
\hline Total & 98 & 100 \\
\hline
\end{tabular}

Sources: Researcher's Field Survey, 2015

From the table 19 revealed that $86(87.8 \%)$ respondents agreed (strongly agreed and agreed) that conflict leads to low-level of employees' performance, while $6(6.1 \%)$ respondents are undecided and 6 (6.1\%) respondents disagreed to the statement.

Table 19. Conflict leads to low-level of employees' performance

\begin{tabular}{|c|c|c|}
\hline Responses & Frequency & Percentage \\
\hline Strongly Agreed & 52 & 53.1 \\
\hline Agreed & 34 & 34.7 \\
\hline Undecided & 6 & 6.1 \\
\hline Disagreed & 6 & 6.1 \\
\hline Strongly Disagreed & - & - \\
\hline Total & 98 & 100 \\
\hline
\end{tabular}

Sources: Researcher's Field Survey, 2015

Table 20 revealed that $72(73.5 \%)$ respondents agreed (strongly agreed and agreed) that conflict leads to high - resistance to change, while $8(8.2 \%)$ respondents are undecided and $18(18.4 \%)$ respondents disagreed to the statement.

Table 20. Conflict leads to high - resistance to change

\begin{tabular}{|c|c|c|}
\hline Responses & Frequency & Percentage \\
\hline $\mathbf{1}$ & $\mathbf{2}$ & $\mathbf{3}$ \\
\hline Strongly Agreed & 44 & 44.9 \\
\hline
\end{tabular}


A. J. Adewole, K. J. Ogunyemi, T. W. Otapo. Implications of Effective Conflict Management on Organizational Performance: Case Study of Nigerian Bottling Company PLC

Continue Table 20

\begin{tabular}{|c|c|c|}
\hline $\mathbf{1}$ & $\mathbf{2}$ & $\mathbf{3}$ \\
\hline Agreed & 28 & 28.6 \\
\hline Undecided & 8 & 8.2 \\
\hline Disagreed & 18 & 18.4 \\
\hline Strongly Disagreed & - & - \\
\hline Total & 98 & 100 \\
\hline
\end{tabular}

Sources: Researcher's Field Survey, 2015

Table 21 revealed that $88(89.8 \%)$ respondents agreed (strongly agreed and agreed) conflicts interfere with group cohesiveness and create interpersonal hostility in such a way that members may become unwilling to work with each other in achieving the organizational objectives, while $8(8.2 \%)$ respondents are undecided and $2(2 \%)$ respondents disagreed to the statement.

Table 21. Conflicts interfere with group cohesiveness and create interpersonal hostility in such a way that members may become unwilling to work with each other in achieving the organizational objectives

\begin{tabular}{|c|c|c|}
\hline Responses & Frequency & Percentage \\
\hline Strongly Agreed & 34 & 34.7 \\
\hline Agreed & 54 & 55.1 \\
\hline Undecided & 8 & 8.2 \\
\hline Disagreed & 2 & 2 \\
\hline Strongly Disagreed & - & - \\
\hline Total & 98 & 100 \\
\hline
\end{tabular}

Sources: Researcher's Field Survey, 2015

It can be inferred from table 22 revealed that $68(69.4 \%)$ of the respondents agreed (strongly agreed and agreed) to the assertion unresolved conflict brings poor communication within the organization and by extension improved organizational performance, $14(14.3 \%)$ respondents were undecided, while 16 $(16.3 \%)$ respondents disagreed (disagreed and strongly disagreed) with the statement.

Table 22. Unresolved conflict brings poor communication within the organization and by extension improved organizational performance

\begin{tabular}{|c|c|c|}
\hline Responses & Frequency & Percentage \\
\hline Strongly Agreed & 28 & 28.6 \\
\hline Agreed & 40 & 40.8 \\
\hline Undecided & 14 & 14.3 \\
\hline Disagreed & 6 & 6.1 \\
\hline Strongly Disagreed & 10 & 10.2 \\
\hline Total & 98 & 100 \\
\hline
\end{tabular}

Sources: Researcher's Field Survey, 2015

From the table 23 shows that $44(44.9 \%)$ respondents agreed (strongly agreed and agreed) that avoidance strategies seek to put off conflict indefinitely, while $22(22.4 \%)$ respondents are undecided and $32(32.7 \%)$ respondents disagreed to the statement. 
A. J. Adewole, K. J. Ogunyemi, T. W. Otapo. Implications of Effective Conflict Management on Organizational Performance: Case Study of Nigerian Bottling Company PLC

Table 23. It has been contended that avoidance strategies seek to put off conflict indefinitely

\begin{tabular}{|c|c|c|}
\hline Responses & Frequency & Percentage \\
\hline Strongly Agreed & 6 & 6.1 \\
\hline Agreed & 38 & 38.8 \\
\hline Undecided & 22 & 22.4 \\
\hline Disagreed & 32 & 32.7 \\
\hline Strongly Disagreed & - & - \\
\hline Total & 98 & 100 \\
\hline
\end{tabular}

Sources: Researcher's Field Survey, 2015

Table 24 shows that $88(89.7 \%)$ respondents agreed (strongly agreed and agreed) that there is a positive relationship between conflict and avoidance and improved organizational performance, while 2 $(2 \%)$ respondents are undecided and $8(8.2 \%)$ respondents disagreed to the statement.

Table 24. It is believed that there is a positive relationship between conflict and avoidance and improved organizational performance

\begin{tabular}{|c|c|c|}
\hline Responses & Frequency & Percentage \\
\hline Strongly Agreed & 22 & 22.4 \\
\hline Agreed & 66 & 67.3 \\
\hline Undecided & 2 & 2 \\
\hline Disagreed & 8 & 8.2 \\
\hline Strongly Disagreed & - & - \\
\hline Total & 98 & 100 \\
\hline
\end{tabular}

Sources: Researcher's Field Survey, 2015

Table 25 revealed that $49(50 \%)$ of the respondents agreed to strongly agree that the use of a wellstructured schedule of duty in an organization reduces indecent of conflict, $49(50 \%)$ respondents agreed with the statement.

Table 25. It is obvious that the use of a well-structured schedule of duty in an organization reduces indecent of conflict

\begin{tabular}{|c|c|c|}
\hline Responses & Frequency & Percentage \\
\hline Strongly Agreed & 49 & 50 \\
\hline Agreed & 49 & 50 \\
\hline Undecided & - & - \\
\hline Disagreed & - & - \\
\hline Strongly Disagreed & - & - \\
\hline Total & 98 & 100 \\
\hline
\end{tabular}

Sources: Researcher's Field Survey, 2015

Table 26 above revealed that $43(43.9 \%)$ of the respondents agreed to strongly agree that putting in place a formal procedure for conflict resolution can prevent future conflict, $51(52 \%)$ respondents agreed and $4(4.1 \%)$ choose undecided with the statement.

Table 26. It is attested that putting in place a formal procedure for conflict resolution can prevent future conflict

\begin{tabular}{|c|c|c|}
\hline Responses & Frequency & Percentage \\
\hline $\mathbf{1}$ & $\mathbf{2}$ & $\mathbf{3}$ \\
\hline Strongly Agreed & 43 & 43.9 \\
\hline Agreed & 51 & 52 \\
\hline Undecided & 4 & 4.1 \\
\hline Disagreed & - & - \\
\hline
\end{tabular}


A. J. Adewole, K. J. Ogunyemi, T. W. Otapo. Implications of Effective Conflict Management on Organizational Performance: Case Study of Nigerian Bottling Company PLC

Continue Table 26

\begin{tabular}{|c|c|c|}
\hline $\mathbf{1}$ & $\mathbf{2}$ & $\mathbf{3}$ \\
\hline Strongly Disagreed & - & - \\
\hline Total & 98 & 100 \\
\hline
\end{tabular}

Sources: Researcher's Field Survey, 2015

Table 27 shows that $29(29.6 \%)$ of the respondents agreed to strongly agree that effective conflict management leads to improve organization performance, $67(68.4 \%)$ respondents agreed and $2(2 \%)$ choose undecided with the statement.

Table 27. Effective conflict management leads to improve organization performance

\begin{tabular}{|c|c|c|}
\hline Responses & Frequency & Percentage \\
\hline Strongly Agreed & 29 & 29.6 \\
\hline Agreed & 67 & 68.4 \\
\hline Undecided & 2 & 2 \\
\hline Disagreed & - & - \\
\hline Strongly Disagreed & - & - \\
\hline Total & 98 & 100 \\
\hline
\end{tabular}

Sources: Researcher's Field Survey, 2015

Table 28 shows that $30(30.6 \%)$ of the respondents agreed to strongly agree that the use of a wellstructured schedule of duty in an organization will reduce the incident of conflicts, 60 (61.2\%) respondents agreed and $8(8.2 \%)$ choose undecided with the statement.

Table 28. Do you agree that the use of a well-structured schedule of duty in an organization will reduce the incident of conflicts

\begin{tabular}{|c|c|c|}
\hline Responses & Frequency & Percentage \\
\hline Strongly Agreed & 30 & 30.6 \\
\hline Agreed & 60 & 61.2 \\
\hline Undecided & 8 & 8.2 \\
\hline Disagreed & - & - \\
\hline Strongly Disagreed & - & - \\
\hline Total & 98 & 100 \\
\hline
\end{tabular}

Sources: Researcher's Field Survey, 2015

The significance of this section is to validate the hypotheses that were formulated for this study. This is required in order to accept or reject the relevant tentative statements.

Table 29. Model Summary

\begin{tabular}{|c|c|c|c|c|}
\hline Model & $\mathrm{R}$ & $\mathrm{R}$ Square & Adjusted R Square & Std. The error of the Estimate \\
\hline 1 & $.324^{\mathrm{a}}$ & .105 & .095 & .390556 \\
\hline \multicolumn{5}{|l}{} \\
Predictors: (Constant), Conflict; Dependent Variance: Performance
\end{tabular}

The value of the $R^{2}$ is 0.105 , this means that $10.5 \%$ changes in the dependent variable (i.e. improve organizational performance) can be explained by the independent variable (i.e. conflict).

The value of the $R$, which is the correlation coefficient, is 0.324 , this simplifies that there is a moderate positive relationship between conflict management and improve organizational performance. 
A. J. Adewole, K. J. Ogunyemi, T. W. Otapo. Implications of Effective Conflict Management on Organizational Performance: Case Study of Nigerian Bottling Company PLC

Table 30. The results of ANOVA

\begin{tabular}{|c|c|c|c|c|c|c|}
\hline \multicolumn{2}{|c|}{ Model } & Sum of Squares & Df & Mean Square & F & Sig. \\
\hline \multirow{3}{*}{1} & Regression & 1.713 & 1 & 1.713 & 11.234 & $.001^{\mathrm{a}}$ \\
\cline { 2 - 7 } & Residual & 14.643 & 96 & .153 & & \\
\cline { 2 - 7 } & \multicolumn{2}{|c|}{ Total } & 16.357 & 97 & & \\
\hline \multicolumn{7}{|c|}{ a. Predictors: (Constant), Conflict; b. Dependent Variable: Performance } \\
\hline
\end{tabular}

Analysis of variance (ANOVA) provides information concerning the breakdown of total variation in the dependent variable into addictive components in that analysis of variance (ANOVA) is not interested in the degree of impacts of the independent variable on the dependent variable as it only establishes whether any relationship or significant relationship exists between the two variables. The F-ratio of 11.234 and the $p$-value of 0.001 which is less than 0.05 significant level, shows that the overall best fit of the model is also satisfactory.

Table 31. Coefficients

\begin{tabular}{|c|c|c|c|c|c|c|}
\hline \multicolumn{2}{|c|}{ Model } & \multicolumn{2}{|c|}{ Unstandardized Coefficients } & Standardized Coefficients & Sig. \\
\cline { 3 - 5 } & B & Std. Error & Beta & & \\
\hline 1 & (Constant) & 1.011 & .281 & & 3.601 & .001 \\
\cline { 2 - 6 } & Conflict & .503 & .150 & .324 & 3.352 & .001 \\
\hline \multicolumn{7}{|c|}{ a. Dependent Variable: Performance } \\
\hline
\end{tabular}

The coefficients table above provides us with the necessary information to predict improve organizational performance from conflict management. Also, it helps to determine whether conflict management contributes significantly to organizational performance. From table 31, the regression equation is presented thus:

$$
\begin{aligned}
& Y=a+b x+U i=1.011+0.281 x+U i \\
& T=(3.601)(3.352)
\end{aligned}
$$

where: $Y=$ Dependent variable (improve organizational performance); $X=$ Independent variable (Conflict management); $a=$ Intercept; $b=$ Slope; Ui= Error of stochastic variable.

Thus, the effect of conflict management leads to improved organizational performance can be defined as: a unit increase in conflict management leads to $50.3 \%$ increase in improved organizational performance.

Based on the above results, we reject the null hypothesis which says that effective conflict management does not lead to improve organizational performance and therefore accept the alternative hypothesis which affirms that effective conflict management leads to improve organizational performance.

This study has examined the impact of effective conflict management on organizational performance in the case study of Nigerian Bottling Company PLC. In the course of this, it has reviewed relevant literature to show different views of conflicts in an organization.

An organization exists to provide goods and services that people desire. These goods and services are the products of the behaviours of workers who occupy different levels of the organizational structure. These people have different cultures, skills and educational background, as well as different perceptions, roles, expectations and values. Conflict is a major factor that can throw parties into a state of incompatibility in their perception of the issue at hand or issue of interest. Though, there are other factors that can contribute to the creation of conflict in organizations like, task interdependence, scarce resources, goal 
incompatibility, communication failures, individual differences and poorly designed reward system. Conflict is an unpleasant fact in any organization as long as people compete for jobs, resources, power, recognition and security. Organizational conflict can be regarded as a dispute that occurs when interests, goals or values of different individuals or groups are incompatible with each other. Conflict is a part of organizational life and may occur between individuals, between the individual and the group, and between groups. A successful approach to conflict management is to improve the performance of an organization and not to eliminate conflict or to avoid it but to learn how to manage it creatively and constructively. Having analysed, discussed and interpreted the data collected for this study, it is imperative to make a certain recommendation that could to improve the conflict management situations and improve organizational performance. Therefore, the following recommendations are essential:

1. Organizations should manage identified conflicts effectively to improve organizational performance.

2. There should be a clearly defined task allocation, which could lead to job satisfaction and enrichment driven, in order to reduce the rate of conflict.

3. The dispute settlement procedure should be well circulated and implemented among the warring parties without fear or favour.

4. The emergence of conflict does arise as a result of overlapping of responsibilities, however, an attempt should be made to design duties among workers, in such a way that will enhance efficiency.

5. Managers should imbibe the culture of good remuneration package through motivation since motivation will go a long way in improving productivity and reduce conflict.

6. Management should maintain and create a conducive environment to strengthen the cordiality between the top-level managers and subordinates because autocratic leadership style can easily result in inefficiency and crisis.

7. Communication and effective flow of information should be encouraged so as to discourage any form of communication breakdown.

8. Customers' satisfaction should be given adequate priority so that the employees will not suffer undue punishment by the management.

Author Contributions: conceptualization, A.J. and K. J.; methodology, T. W.; software, K. J.; validation, T. W., K. J. and A. J.; formal analysis, A. J.; investigation, A. J.; resources, K. J.; data curation, K. J.; writing - original draft preparation, K. J.; writing - review and editing, A. J.; visualization, T. W.; supervision, T. W.; project administration, K. J.; funding acquisition, K. J.

\section{References} 530

Adomi E. E., Anie SO, 2005. Conflict Management in Nigerian University Libraries. Journal of Library Management, 27(8): 520-

Akaniji, T. (2005) Perspectives on Workplace Conflict Management and New Approaches for the Twenty-First Century. In Albert, I. O. (Ed) Perspectives on Peace and Conflict in Africa Essays in Honour of General (Dr.) Abdusalami A. Abubakar Ibadan: John Arches Publishers.

Albert, I. O. (2001). Introduction to Third Party Intervention in Community Conflicts. Ibadan: John Arches Publishers.

Azamosa, O. (2004). Industrial Conflict in Nigerian Universities: The Case of the Academic Staff Union of the University Teaching Strike of Dec. 2002 - June 2003. Department of Sociology, Anthropology and Applied Science, Bristol University.

Bagshaw, M. (1998). Conflict Management and Mediation: Key Leadership Skills for the Millennium, Industrial and Commercial Training. Vol. 30 No. 6.

Barclay, D. (1991). Interdepartmental Conflict in Organisational Buying: The Impact of the Organisational Context. Journal of Marketing Research, Vol. 28 No. 2.

Barney, J. (2008). Firm Resources and Sustained Competitive Advantage. Journal of Management 1(17)

Brewer N, Mitchell P, Weber N, 2002. Gender role, organizational status, and conflict management styles. The International Journal of Conflict Management, 13 (1): 78-94.

Daft, R. L. (2009) Organisation Theory and Design (11th Ed).South-Western College Publishing. USA: Thomson Learning. 
A. J. Adewole, K. J. Ogunyemi, T. W. Otapo. Implications of Effective Conflict Management on Organizational Performance: Case Study of Nigerian Bottling Company PLC

Darling, J., Walker, W. (2007), Effective Conflict Management: Use of the Behavioural Style Model, Leadership and Organisation Development Journal, Vol. 22 No. 5Education Ltd.

Deutch, M. and Coleman, P. T. (2006).The Handbook of Conflict Resolution. San Francisco: Jossy Bass.

Edwards C, Walton G, 2000. Change and conflict. Library Management, 21 (1): 35-41.

Fadipe J. O. (2000) Efficiency Indicators For Quality Control on Nigeria. A Journal of NIEPA Ondo (Nigeria).

Hansen, G. S. and Wernerfelt (2004). Determinants of Firm Performance: Relative Importance of Economics and Organisational

Factors. Strategic Management Journal 10 (5)

Hart, B. (2000). Conflict in the workplace. Behaviour consultants, P.C

Havenga, W. (2004).Conflict Management within a Local Government Environment.M.A. Thesis, Potchefstroom University.

Hefferman, M. M. and Flood, P.C. (2006).An Exploration of the Relationship between Managerial Competencies, Organisational,

Characteristics; and Performance in Irish Organisations. Journal of European Industrial Training, Vol. 23, No. 11

Henry, O. (2009). Organisational Conflict and its Effects on Organisational Performance. Research Journal of Business

Management. Vol. 21, No. 8

Ikeda AA, Veludo-de-Oliveira, Campomar MC, 2005. Organizational conflicts perceived by marketing executives. Electronic

Journal of Business and Organization Studies, 10 (1): 22-28.

Imazai $\mathrm{K}$, Ohbuchi K, 2002. Conflict resolution and procedural fairness in Japanese work organizations. Japanese

Psychological Research, 44 (2): 107-12.

Jones and George (2003) Organizational Conflict, Negotiation, Politics, and Change, contemporary management 3rd edition

PowerPoint Presentation by Charlie Cook The McGraw-Hill Companies, Inc. Jones GR, Gorge JM, Hill CWL, 2000. Contemporary Management, McGraw-Hill, Boston, MA. Second Edition, Henry 0. 2009,

Organizational Conflict and its effects on Organizational Performance. Research Journal of Business Management, 2 (1): 16-24. Jones, T. S. (2000). «Emotional Communication in Conflict: Essence and Impact». In Eadie, W.And Nelson P. (Eds).The

Language of Conflict and Resolution, Sage Thousand Oaks.

Jones, T. S. (2000). «Emotional Communication in Conflict: Essence and Impact». In Eadie, W.And Nelson P. (Eds).The

Language of Conflict and Resolution, Sage Thousand Oaks.

Jung S, 2003. The effects of organizational culture on conflict resolution in marketing. Journal of American Academy of

Business, 3: 242-46.

Kreitner, R. and Kinicky, A. (2001) Organisational Behaviour. New York: McGraw-Hill.

Maltz, E. and Kohli, A. (2000).Reducing Marketing's Conflict with other Functions: The Differential Effects of Integrating

Mechanisms.Journal of the Academy of Marketing Science, Vol. 28 No. 4.

Mayer, B. (2002). The Dynamics of Conflict Resolution. San Francisco: Jossy Bass.

Mcfoland, D. (1970): Management Foundation and Principles; New York Macmillan Publishing Company

Mgbekem, S. J. (2004). Management of University Education in Nigeria. Calabar: University Of Calabar Press

Miller, E. C. And King, M. E. (2005). A Glossan of Years and Concepts in Peace and Conflict Studies (2nd Edition), Addis

Ababa: University Of Peace African Programme.

Ngu, S. M. (2008). Management Principles and Workers Motivation in Nigeria. Zaria: Gaskiya Corporation.

Olakunle, A. O. (2008). Organisational Dynamics. Ibadan, Nigeria: Spectrum Books Limited.

Rahim, M. A. (2002). Towards a Theory of Managing Organisational Conflict. The International Journal of Conflict Management, $13(20)$

Richardo, R. and Wade, D. (2010). Corporate Performance Management: How to Build a Better Organisation through

Measurement Driven Strategies Alignment. Butterworth Heinemann.

Rivers, E. (2005). Management of Difference and Conflict in Organisation: A Guide for Busy HR Professional. Centre for

Effective Dispute Resolution

Robbins, S. P., and Judge, T. A. (2009). Organisational Behaviour. 13th (ed) USA: Prentice Hall, New Jersey.

Robbins, S.P. (2005). Organizational Behaviour, New Jersey, Prentice Hall Inc

Schramm-Nielsen, J. (2002) «Conflict Management in Scandinavia» Department of Intemational Communication and

Management, Copenhangan Business School, Denmark.

Stephen P. Robbins (1993): Organizational Behavior, Concepts, Controversies and Applications, 6th ed. San Diego State University, Prentice Hall, Eaglewood cliffs, New Jersey. P. 445-462.

А. Дж. Адеволе, Університет Адекунле Аджасін (Нігерія);

К. Дж. Огун'ємі, Університет Адекунле Аджасін (Нігерія)

T. B. Oтапо, Ph.D., Університет Адекунле Аджасін (Нігерія).

Взаємозв'язок між конфлікт-менеджментом та ефективністю діяльності компанії: на прикладі компанії Ботлер в Hirepiï

У статті авторами систематизовано аргументи та контраргументи щодо впливу ефективного конфллікт-менеджменту на показники діяльності компанії. Основною метою дослідження $\epsilon$ вивчення взаємозв'язку між ефрективністю конфрлікт-менеджменту та 
A. J. Adewole, K. J. Ogunyemi, T. W. Otapo. Implications of Effective Conflict Management on Organizational Performance: Case Study of Nigerian Bottling Company PLC

прибутковістю компанії в Нігерії. При цьому авторами досліджено та узагальнено причини виникнення конфрліктів, підходи до їх класифрікації, умови розвитку конфрліктних ситуацій та стратегій управління ними, а також засоби урегулювання їх з метою підвищення ефективності діяльності компанії. 3 метою перевірки висунутих гіпотез у статті авторами було застосовано регресійний аналіз. Дані для аналізу були зібрані шляхом анкетування. При цьому вибірку даних сформовано на основі опрацювання відповідей 98 респондентів. Емпіричні результати регресійного аналізу підтвердили гіпотезу, що урегулювання конфрліктних ситуацій сприяє підвищенню ефективності діяльності компанії. При цьому отримані результати свідчать про наявність позитивного взаємозв'язку між урегулюванням конфрліктів (незалежною змінною) та показниками діяльності компанії (залежною змінною). Таким чином, на основі отриманих результатів дослідження автори сформували низку рекомендацій для організацій, а саме: необхідно ефективно управляти виявленими конфрліктами для того, щоб підвищити прибутковість компанії; з метою зниження рівня конфрліктності, компанії повинні чітко розподіляти обов'язки між працівниками, що сприятиме підвищенню рівня задоволеності працею та матеріального благополуччя; необхідно неупереджено розповсюджувати та реалізовувати процедуру урегулювання суперечок між сторонами конфрлікту; оскільки конфрліктні ситуації виникають внаслідок виконання аналогічних обов'язків, компанія повинна покладати нові обов'язки на працівників, що у свою чергу забезпечить підвищення їх продуктивності; менеджмент компанії повинен удосконалювати систему оплати праці та забезпечувати сприятливе середовище для зміинення дружніх відносин між керівниками вищої ланки та їх підлеглими, оскільки авторитарний стиль управління $\epsilon$ не ефективним у довгостроковій перспективі та спричинює появу низки криз; необхідно налагоджувати комунікації з метою невіліювання асиметрії інфооммації.

Ключові слова: конфлікт-менеджмент, конфлікт, прибутковість, ефективність.

Manuscript received: 10.12 .2018

(c) The author(s) 2019. This article is published with open access at Sumy State University. 